Biljana Jovanović Gavrilović ${ }^{1}$ Mirjana Gligorić ${ }^{2}$
JEL: I31, E01, C43, C38

DOI:10.5937/industrija46-16696

UDC:330.341(4-672EU:497-15)"2007-2016" 330.45:519.237.8

Original Scientific Paper

\title{
Fundamental drivers of prosperity in the European Union and Western Balkans countries $^{3}$
}

\author{
Article history: \\ Received: 27 January 2018 \\ Sent for revision: 6 February 2018 \\ Received in revised form: 6 March 2018 \\ Accepted: 6 March 2018 \\ Available online: 20 March 2018
}

\begin{abstract}
In this paper the aim is to identify key drivers that have contributed the most to the prosperity of European Union and Western Balkan countries in the 2007-2016 period. Empirical analysis is based on data for cumulative growth rate of values of nine original Legatum Prosperity Index (LPI) pillars and on implementation of Multivariate Data Analysis. Using Principal Component Analysis, four principal components are obtained and we named them: Economic Environment, Social Infrastructure, Institutional Framework and Life Conditions. Based on standardised score values of four new variables, we distinguish the countries that had the highest positive and negative score in each component. With cluster analysis based on LPI pillars growth rates, four clusters of countries have been formed: the first cluster consists of three Western Balkan countries, the second and third of, respectively, ten and four mostly new EU member state countries, and fourth of fourteen predominantly "old" EU member countries. The analysis points out the fundamental drivers of prosperity in countries belonging to different clusters according to changes in values of nine LPI pillars in the previous decade. In all observed countries it is possible to identify certain similarities in the change of components of prosperity, as they are EU members or candidates for membership.
\end{abstract}

\footnotetext{
${ }^{1}$ University of Belgrade, Faculty of Economics, bgavrilo@ekof.bg.ac.rs

2 University of Belgrade, Faculty of Economics

${ }^{3}$ This paper is a result of research as part of projects No. 179065, No. 179005 and III46001 , financed by the Ministry of Education, Science and Technological Development of the Republic of Serbia.
} 
Jovanović Gavrilović B., Gligorić M.: Fundamental drivers of prosperity in the...

Keywords: Legatum Prosperity Index, Principal Component Analysis, Cluster Analysis, Drivers of Prosperity

\section{Fundamentalni pokretači prosperiteta u zemljama Evropske unije i Zapadnog Balkana}

Apstrakt: Cilj ovog rada je da identifikuje ključne pokretače koji su najviše doprineli prosperitetu zemalja Evropske unije i Zapadnog Balkana u periodu od 2007. do 2016. Empirijska analiza zasnovana je na podacima kumulativnih stopa rasta vrednosti devet stubova indeksa prosperiteta Legatum instituta (LPI), kao i na implementaciji Multivarijacione analize podataka. Pomoću Analize glavnih komponenata, dobili smo četiri osnovne komponente koje smo nazvali: Ekonomsko okruženje, Socijalna infrastruktura, Institucionalni okvir i Životni uslovi. Na osnovu standardizovanih vrednosti skorova četiri nove varijable, izdvojili smo zemlje sa najvišim pozitivnim i negativnim skorom u svakoj komponenti. Klaster analizom formirana su četiri klastera od kojih se prvi sastoji od tri zemlje Zapadnog Balkana, drugi i treći od deset i četiri, većinom novih članica EU, respektivno, a četvrti od 14 mahom "starih" članica EU. Analiza ukazuje na ključne pokretače prosperiteta u zemljama koje pripadaju različitim klasterima na osnovu promena vrednosti devet stubova indeksa prosperiteta u protekloj deceniji. U svim posmatranim zemljama je moguće identifikovati određene sličnosti u promenama komponenata prosperiteta, budući da su one članice EU ili kandidati za članstvo u Uniji.

Ključne reči: Legatum indeks prosperiteta, Analiza glavnih komponenata, Klaster analiza, pokretači prosperiteta

\section{Introduction}

Nowadays, different indices attained through synthesizing a great number of indicators are becoming more and more important. Even though the significance and occurrence of GDP in economic publications are still unrivaled, many composite indices were created to cover and control the quality of life in a simple but wholesome way (Stiglitz, Sen, \& Fitoussi, 2009). The indices were created with the goal to cover numerous development aspects simultaneously or to target an individual issue that deserves special attention in modern times. Some of those indices are Human Development Index, Global Competitiveness Index, Happy Planet Index, Misery Index and Global Creativity Index etc (Gligorić, Jovanović Gavrilović \& Savić, 2018). Legatum Prosperity Index is an important index that is paid special attention to in this work in order to identify the main drivers of prosperity in European countries. 
Jovanović Gavrilović B., Gligorić M.: Fundamental drivers of prosperity in the...

Legatum Prosperity Index (LPI) represents an inquiry into the nature of prosperity and the way it was created (Legatum Institute, 2008). The indicator measuring income and wellbeing, which form the index basis, was designed in 2007 by the Legatum Institute. LPI offers an extensive view of prosperity and covers material wealth as well as life satisfaction, i.e. it implies the idea of combining new indicators of subjective wellbeing and the economic measures, with the goal of determining which countries are doing the most to encourage holistic prosperity. Therefore, the index also contains subjective, as well as objective data for measuring prosperity of countries and determinants of that prosperity. The index is the answer to burgeoning interest in wellbeing and prosperity measures and besides economic aspect, it covers other development aspects, which permits the identification of prosperity drivers and causes. LPI is used in this empirical analysis for the reason of the index being holistic, meaning it includes a great number of components. The index has nine components (pillars): Economic Quality, Business Environment, Health, Safety \& Security, Social Capital, Education, Governance, Personal Freedom and Environment (Legatum Institute, 2017, p. 10).

In order to estimate the main drivers of prosperity in selected European countries in previous decade, we implement Multivariate Data Analysis. Precisely for this purpose we use the Principal Component Analysis (PCA) and Cluster Analysis on the data for cumulative value growth of LPI pillars. Using PCA, representative variables (principal components) and their contribution to the change in prosperity of each European country in the observed period can be identified. Besides that, with Cluster Analysis we can identify groups of the observed countries (clusters) based on similarity in the tempo of changes in Prosperity Index pillars.

In Section 2, a short literature review is presented, including papers in which author/s use indicators of development and/or Multivariate Analysis for prosperity analysis. Detailed data explanation is given in Section 3 Prosperity Index, its pillars and the explanation of methodology that we used in our empirical research. The results of empirical analysis are presented in Section 4, and the conclusions in Section 5.

\section{Literature review}

The complexity of studying prosperity is identified by many authors, who underline how important multidisciplinary approach is to the research of this subject and its measurement through creation/usage of synthetic indicators (Jovanović Gavrilović, Gligorić, \& Molnar, 2012; Altaş \& Arikan, 2017; Sima \& Gheorghe, 2017). Moreover, numerous studies emphasize how important 
Jovanović Gavrilović B., Gligorić M.: Fundamental drivers of prosperity in the...

people's subjective assessment of life quality is for the formation of indicators and their components, together with objective data. Numerous indicators are used today to measure countries' wellbeing and social progress and for some time now, it has been noted that composite indices popularity and occurrence in research and economic analysis have been increasing. Synthetic indicators used in literature vary considerably based on their components, pursuant to data sources, calculation methodology, development aspects they focus on, their coverage and so on. Examples of the most used indicators in economic studies are: Human Development Index (HDI), Happy Planet Index (HPI), Better Life Index, Multidimensional Poverty Index (MPI), Legatum Prosperity Index (LPI), etc.

Numerous economic studies use HDI to gauge countries' prosperity over a longer period of time and also to compare them to other countries. On the contrary, we have not found many researches using LPI - only certain analysis for selected European countries by Legatum Institute, e.g. Legatum Institute (2016b).

Authors Biswas and Caliendo (2002) used multivariate analysis on the data for HDI. Using PCA, they combine measures of human development. They obtained the first principal component of the three dimensions that constitute the HDI (life expectancy, education, GDP). Using that component, they generate rankings for 162 countries that are in great part consistent with those of the HDI. Authors see this result as theoretical support for the HDI ranking as an adequate metric system for world countries' development.

Moreover, the paper by authors Giray and Ergut (2014) evaluated countries according to their similarities and differences using the indicators contained in the 2013 Human Development Report: HDI, the Inequality-adjusted HDI, the Gender Inequality Index (GII) and the Multidimensional Poverty Index. The data for countries were analyzed using Multidimensional Scaling analysis (MDS). This assessment had been performed with the assistance of a figure composed in two-dimensional space as a result of MDS analysis on OECD and Eurasian countries' data.

Shaker and Zubalsky (2013) highlighted the importance of sustainable development goals, such as environmental quality, social equity, and economic welfare. They focused on indicators of sustainable development, because there was no consensus regarding the best approach to their design or use. Even though several studies have touched upon the associations between indicators of sustainable development, few have directly addressed the question of how to use multiple measures simultaneously to assess sustainability regionally. The authors present a quantitative and spatial assessment of 25 multi-metric indices across 36 European nations. The goals of this research were to enhance understanding of indicator complexity and provide an example of their simultaneous use for regional assessment. For 
Jovanović Gavrilović B., Gligorić M.: Fundamental drivers of prosperity in the...

testing spatial autocorrelation and multicollinearity, respectively, Global Moran's l-test and Pearson's correlation coefficient $(r)$ analysis were used. From 25 composite indices, an overall rank was also provided for each country. Lastly, for the creation of country bundles of similarity Ward's cluster analysis was used.

Altaş and Arikan (2017) used HDI data of 188 world countries for 2015. Whith implementation of Cluster Analysis they made the development classification of the countries and compared it with United Nation's development classification. The authors interpreted the results and in detailed compared the position of the countries. Also, they concluded that some countries' development class has been changed when the clustering method has changed.

\section{Data and methodology}

In our paper we use the Legatum Institute data regarding the Prosperity Index for the 2007-2016 period. The index, as we already mentioned, has nine components (pillars): Economic Quality, Business Environment, Health, Safety \& Security, Social Capital, Education, Governance, Personal Freedom and Environment. Every pillar contains about 12 variables, or more accurately LPI has a total of 104 variables and includes both objective and subjective data (Legatum Institute, 2016a). LPI data are accessible for most of the world countries and are available from 2007.

The sample of countries includes 31 European countries - 27 EU countries (research covered $27 \mathrm{EU}$ members since Great Britain started the process of leaving this regional integration) and four Western Balkans countries (Serbia, Albania, Montenegro and Macedonia). For empirical analysis, we first calculated cumulative growth rate for each of the Prosperity Index components (pillars) from 2007 to 2016 for the observed countries. As the main part of the empirical analysis, we implemented multivariate analysis - the Principal Component Analysis and Cluster Analysis on the data for cumulative growth rate of LPI pillars.

Using the PCA, we got the principal components that describe the original data accurately enough, that is, they are considerably correlated with the starting components and they encompass a great part of starting data variability. Thus, instead of nine original LPI components/pillars, we got four principal components on which further prosperity analysis is based.

With the help of four principal components and based on the so called score analysis, we distinguish the countries that had the highest positive and negative score in each component - that is, the countries that, within each 
Jovanović Gavrilović B., Gligorić M.: Fundamental drivers of prosperity in the...

principal component, recorded the biggest growth or decline. Using that method, it can be identified which key determinants have contributed the most to the progress of each European country from 2007. Therefore, we can separate countries according to main drivers of their prosperity in 10 years period.

Additionally, through Cluster Analysis, clusters have been formed based on the same data that represent cumulative increase of every prosperity pillar between 2007 and 2016. This analysis allows creating groups of EU and WB countries based on differences and similarities in the tempo of changes in Prosperity Index pillars.

\section{Results and discussion}

Multivariate data analysis techniques which we use for analysis of the specific composite indicator - Legatum Prosperity Index - are described in this section. We use Principal Component Analysis and Cluster Analysis.

The goal of PCA is to explain variance of the observed data with few components that represent uncorrelated linear combinations of the original data (OECD, 2008). First in PCA principal components cover considerable amount of the cumulative variance of the starting data. The absence of correlation in principal components shows that they measure different "statistical dimensions" in the data. Thus, if there is correlation between the original variables and their number is to be reduced while still keeping an important part of the original data variability, PCA is a very useful method, as in our case.

In our analysis, the initial number of variables is nine. The variables we observe are cumulative growth rates of each of the LPI pillars. In order to better understand and group the countries according to the main drivers of prosperity, our goal is to get a smaller number of meaningful variables that led to the LPI growth in the observed sample of countries.

In Table 1 is given the descriptive statistics. The sample includes 31 countries (column Analysis $\mathrm{N}$ ). The Mean column consists of arithmetic mean of cumulative growth rates of each component in the observed countries sample. Thus, on average, the highest value growth is registered in the Environment pillar (12.1\% growth in the given period), while the observed countries on average registered deterioration in the level of pillar Economic Quality $(2.8 \%$ reduction in the period 2007-2016). Standard deviations are given in the second column of the table.

The correlation table points out the presence of a certain linear relationship of pillar changes in the observed countries. By using PCA, we wanted to get a 
Jovanović Gavrilović B., Gligorić M.: Fundamental drivers of prosperity in the...

smaller number of variables - LPI "components", that will be uncorrelated with each other but will truthfully represent the original data and thus facilitate the analysis of the key prosperity drivers in European countries.

Table 1. Descriptive Statistics

\begin{tabular}{|l|r|r|r|}
\hline & Mean & $\begin{array}{c}\text { Std. } \\
\text { Deviation }\end{array}$ & Analysis N \\
\hline econ & -0.028 & 0.044 & 31 \\
\hline busi & 0.091 & 0.105 & 31 \\
\hline gove & 0.002 & 0.070 & 31 \\
\hline educ & 0.018 & 0.019 & 31 \\
\hline heal & 0.012 & 0.020 & 31 \\
\hline safe & 0.021 & 0.024 & 31 \\
\hline pers & 0.025 & 0.052 & 31 \\
\hline soci & 0.025 & 0.062 & 31 \\
\hline envi & 0.121 & 0.081 & 31 \\
\hline
\end{tabular}

Note: econ - Economic Quality, busi - Business Environment, gove - Governance, educ Education, heal - Health, safe - Safety \& Security, soci - Social Capital, pers - Personal Freedom and envi - Environment.

Source: Authors' own calculation

Based on the extracted communality (see Table 2), we see that for the observed variables the percent of the explained variance by principal components that are obtained and kept in the analysis is delectably high, which shows that the key formed components are a good substitute for the original variables (pillars).

Table 2. Communalities

\begin{tabular}{|l|r|r|}
\hline & \multicolumn{1}{|c|}{ Initial } & Extraction \\
\hline econ & 1.000 & 0.786 \\
\hline busi & 1.000 & 0.833 \\
\hline gove & 1.000 & 0.758 \\
\hline educ & 1.000 & 0.719 \\
\hline heal & 1.000 & 0.804 \\
\hline safe & 1.000 & 0.646 \\
\hline pers & 1.000 & 0.850 \\
\hline soci & 1.000 & 0.450 \\
\hline envi & 1.000 & 0.659 \\
\hline
\end{tabular}

Note: a) Extraction Method is PCA; b) econ - Economic Quality, busi - Business Environment, gove - Governance, educ - Education, heal - Health, safe - Safety \& Security, soci - Social Capital, pers - Personal Freedom and envi - Environment.

Source: Authors' own calculation 
Jovanović Gavrilović B., Gligorić M.: Fundamental drivers of prosperity in the...

Figure 1. Scree Plot

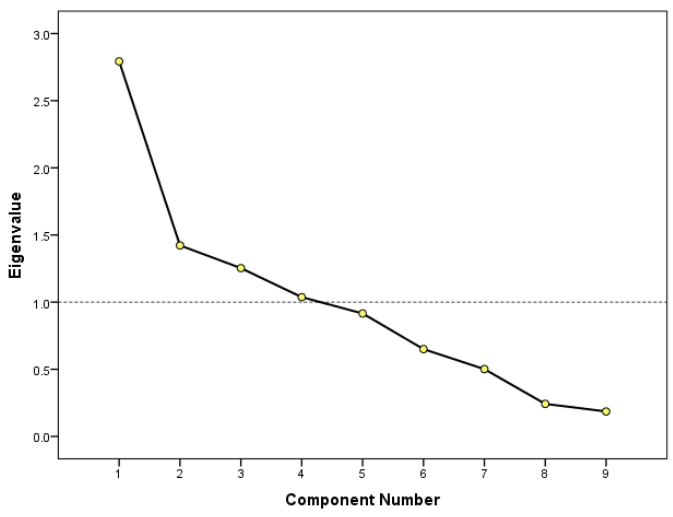

Source: Authors' own calculation

Figure 1 and Table 3 show that there are four principal components whose eigenvalue is above one. Based on variable reduction to four components we manage to simplify the analysis - to reduce nine variables to four with $27.7 \%$ of infomation loss.

Table 3. Total Variance Explained

\begin{tabular}{|c|c|c|c|c|c|c|c|c|c|}
\hline \multirow[b]{2}{*}{ Component } & \multicolumn{3}{|c|}{ Initial Eigenvalues } & \multicolumn{3}{|c|}{$\begin{array}{l}\text { Extraction Sums of Squared } \\
\text { Loadings }\end{array}$} & \multicolumn{3}{|c|}{$\begin{array}{c}\text { Rotation Sums of Squared } \\
\text { Loadings }\end{array}$} \\
\hline & Total & $\begin{array}{c}\% \text { of } \\
\text { Variance }\end{array}$ & $\begin{array}{c}\text { Cumulative } \\
\%\end{array}$ & Total & $\begin{array}{c}\% \text { of } \\
\text { Variance }\end{array}$ & $\begin{array}{c}\text { Cumulative } \\
\%\end{array}$ & Total & $\begin{array}{c}\% \text { of } \\
\text { Variance }\end{array}$ & $\begin{array}{c}\text { Cumulative } \\
\%\end{array}$ \\
\hline 1 & 2.793 & 31.028 & 31.028 & 2.793 & 31.028 & 31.028 & 2.332 & 25.908 & 25.908 \\
\hline 2 & 1.422 & 15.802 & \begin{tabular}{|c|}
46.830 \\
\end{tabular} & 1.422 & \begin{tabular}{|c|}
15.802 \\
\end{tabular} & 46.830 & 1.503 & 16.695 & 42.603 \\
\hline 3 & 1.253 & 13.925 & 60.756 & 1.253 & 13.925 & 60.756 & 1.377 & 15.299 & 57.902 \\
\hline 4 & \begin{tabular}{|c|}
1.037 \\
\end{tabular} & 11.525 & \begin{tabular}{|l|}
72.280 \\
\end{tabular} & 1.037 & 11.525 & 72.280 & 1.294 & 14.378 & 72.280 \\
\hline 5 & 0.916 & 10.174 & 82.454 & & & & & & \\
\hline 6 & 0.650 & 7.223 & 89.676 & & & & & & \\
\hline 7 & 0.501 & 5.570 & \begin{tabular}{|c|}
95.247 \\
\end{tabular} & & & & & & \\
\hline 8 & 0.242 & 2.689 & 97.936 & & & & & & \\
\hline 9 & 0.186 & 2.064 & 100.000 & & & & & & \\
\hline
\end{tabular}

Note: Extraction Method is PCA

Source: Authors' own calculation

In the Rotated Component Matrix (Table 4), we see the correlation level of the four principal components with the initial variables in the model. For the 
Jovanović Gavrilović B., Gligorić M.: Fundamental drivers of prosperity in the...

rotation method we used the Varimax method - orthogonal rotation method that minimizes the number of variables that have high loadings on each factor, so that the method simplifies the interpretation of the factors. According to the results, only growth rates of Health and Economic Quality are related to two principal components, while the rest of the variables are entirely related to only one principal component. The first principal component explains the greatest part of variability (25\%, see Table 3 ) and it is the most closely correlated with cumulative change in Business Environment and Governance, as well as Economic Quality and Social Capital. Consequently, values in the table show that countries with higher growth rate in Business Environment are those with higher growth in Governance, Economic Quality and Social Capital. Each of the remaining three components explain approximately $15 \%$ of variability each, where the second principal component is the most correlated with change in values in Education and Safety and Security, the third with values change in Personal Freedom and Health and the fourth with values change in Environment, Economic Quality and Health variables. This shows that the countries that registered the highest education growth at the same time had the highest Safety and Security growth, while the countries that had higher Personal Freedom or Environment and Economic Quality growth are the countries that registered population health improvement.

For the purpose of a simpler interpretation, we can name the four key components based on what they measure. We can thus name the first component Economic Environment, the second one Social Infrastructure, the third one Institutional Framework, and the fourth one Life Conditions.

Table 4. Rotated Component Matrix

\begin{tabular}{|l|r|r|r|r|}
\hline \multirow{2}{*}{} & \multicolumn{4}{|c|}{ Component } \\
\cline { 2 - 5 } & \multicolumn{1}{|c|}{$\mathbf{1}$} & \multicolumn{1}{|c|}{2} & \multicolumn{1}{c|}{3} & \multicolumn{1}{c|}{$\mathbf{0}$} \\
\hline econ & $\mathbf{0 . 6 4 4}$ & 0.118 & 0.125 & $\mathbf{0 . 5 8 5}$ \\
\hline busi & $\mathbf{0 . 8 1 3}$ & 0.037 & -0.413 & 0.034 \\
\hline gove & $\mathbf{0 . 8 3 8}$ & 0.204 & 0.115 & -0.017 \\
\hline educ & -0.012 & $\mathbf{0 . 8 3 3}$ & 0.019 & -0.158 \\
\hline heal & 0.217 & 0.437 & $\mathbf{0 . 5 3 6}$ & $\mathbf{0 . 5 2 8}$ \\
\hline safe & 0.223 & $\mathbf{0 . 7 3 2}$ & -0.126 & 0.212 \\
\hline pers & -0.012 & -0.141 & $\mathbf{0 . 8 8 5}$ & -0.215 \\
\hline soci & $\mathbf{0 . 6 6 4}$ & 0.019 & 0.090 & -0.025 \\
\hline envi & -0.128 & -0.076 & -0.286 & $\mathbf{0 . 7 4 5}$ \\
\hline
\end{tabular}

Note: a) Extraction Method is PCA and Rotation Method is Varimax with Kaiser Normalization. b) Bolded numbers represent loadings greater than 0.5 (absolute values); c) econ - Economic Quality, busi - Business Environment, gove - Governance, educ - Education, heal - Health, safe Safety \& Security, soci - Social Capital, pers - Personal Freedom and envi - Environment.

Source: Authors' own calculation 
Jovanović Gavrilović B., Gligorić M.: Fundamental drivers of prosperity in the...

Table 5. Principal component scores

\begin{tabular}{|l|c|c|c|c|}
\hline & Component 1 & Component 2 & Component 3 & Component 4 \\
\hline Albania & $\mathbf{2 . 4 3}$ & $\mathbf{- 1 . 5 9}$ & 0.14 & $\mathbf{- 1 . 3 4}$ \\
\hline Austria & -0.93 & 0.08 & $\mathbf{1 . 0 1}$ & -0.37 \\
\hline Belgium & -0.68 & $\mathbf{- 1 . 4 6}$ & 0.01 & $\mathbf{1 . 0 9}$ \\
\hline Bulgaria & -0.14 & -0.34 & $\mathbf{- 1 . 2 4}$ & $\mathbf{1 . 2 2}$ \\
\hline Croatia & 0.61 & -0.39 & -0.03 & -0.08 \\
\hline Cyprus & -0.78 & -0.18 & $\mathbf{- 1 . 1 4}$ & $\mathbf{- 1 . 8 1}$ \\
\hline Czech Republic & 0.40 & 0.88 & -0.69 & -0.10 \\
\hline Denmark & $\mathbf{- 1 . 0 2}$ & -0.95 & 0.89 & 0.57 \\
\hline Estonia & 0.49 & $\mathbf{1 . 3 8}$ & 0.65 & -0.22 \\
\hline Finland & -0.41 & $\mathbf{1 . 0 2}$ & $\mathbf{1 . 1 0}$ & $\mathbf{- 1 . 2 6}$ \\
\hline France & -0.93 & -0.20 & 0.60 & -0.14 \\
\hline Germany & 0.10 & -0.59 & 0.62 & 0.20 \\
\hline Greece & -0.47 & -0.91 & $\mathbf{- 1 . 4 4}$ & $\mathbf{- 1 . 7 4}$ \\
\hline Hungary & $\mathbf{- 1 . 2 5}$ & 0.00 & $\mathbf{- 1 . 6 7}$ & $\mathbf{1 . 3 5}$ \\
\hline Ireland & -0.63 & 0.95 & 0.66 & $\mathbf{- 1 . 5 0}$ \\
\hline Italy & -0.80 & -1.01 & -0.10 & -0.94 \\
\hline Latvia & 0.59 & $\mathbf{1 . 6 1}$ & -0.21 & 0.48 \\
\hline Lithuania & 0.68 & $\mathbf{2 . 3 9}$ & 0.83 & 0.18 \\
\hline Luxembourg & -0.47 & 0.76 & 0.58 & -0.31 \\
\hline Macedonia & $\mathbf{2 . 6 4}$ & -0.01 & $\mathbf{- 1 . 2 5}$ & $\mathbf{1 . 2 8}$ \\
\hline Malta & 0.36 & 0.14 & $\mathbf{2 . 7 8}$ & $\mathbf{1 . 7 9}$ \\
\hline Montenegro & $\mathbf{1 . 2 6}$ & -0.06 & -0.78 & -0.59 \\
\hline Netherlands & -0.99 & -0.69 & -0.18 & 0.75 \\
\hline Poland & 0.54 & $\mathbf{1 . 6 8}$ & -0.89 & 0.35 \\
\hline Portugal & 0.01 & -0.75 & $\mathbf{1 . 1 2}$ & -0.91 \\
\hline Romania & $\mathbf{1 . 2 5}$ & $\mathbf{- 1 . 4 6}$ & 0.99 & 0.43 \\
\hline Serbia & $\mathbf{1 . 1 4}$ & -0.43 & -0.67 & -0.41 \\
\hline Slovakia & -0.65 & 0.62 & $\mathbf{- 1 . 0 9}$ & -0.08 \\
\hline Slovenia & -0.88 & -0.21 & -0.77 & $\mathbf{2 . 1 5}$ \\
\hline Spain & $\mathbf{- 1 . 1 7}$ & 0.78 & -0.60 & -0.17 \\
\hline Sweden & -0.29 & $\mathbf{- 1 . 0 7}$ & 0.73 & 0.13 \\
\hline Sar & & & & \\
\hline
\end{tabular}

Source: Authors' own calculation

In Table 5 are given the score values for the principal components for each observed country based on the carried out analysis. In fact, four variables of factor scores are created, that consist of standardized scores for each main component for each individual country. Based on those, we conclude that:

- It is noticeable that Serbia, Albania, Macedonia, Montenegro (WB countries) and Romania have a very high standardized score value in 
Jovanović Gavrilović B., Gligorić M.: Fundamental drivers of prosperity in the...

component 1, meaning that their progress in the 2007-2016 period was in great part a consequence of Economic Environment improvement. On the other side, greater negative value of this component was registered in Denmark, Hungary and Spain.

- Exceptionally high positive value in component 2 is registered in Baltic countries and Poland, which shows that their prosperity was based on Social Infrastructure improvement. Negative score in component 2 is present in Albania, Belgium, Romania and Sweden.

- The change in Institutional Framework separates Austria, Finland, Malta and Portugal on one side (with considerably high positive score) from Bulgaria, Cyprus, Greece, Hungary, Macedonia and Slovakia on the other (with notably high negative score), regarding prosperity growth.

- Numerous countries registered positive and high score in component 4 that we named Life Conditions: Belgium, Bulgaria, Hungary, Macedonia, Malta and Slovenia, while markedly negative score was registered in Albania, Cyprus, Finland, Greece and Ireland.

Through PCA, we managed to identify four principal components and get scores for each country, which we used to identify the key prosperity drivers for European countries in previous decade. It is important that the components are not correlated with each other, which we confirmed through Scatterplot observation (see Figure 2). Correlation coefficients that eqaul zero also confirm that.

Figure 2. Scatterplot

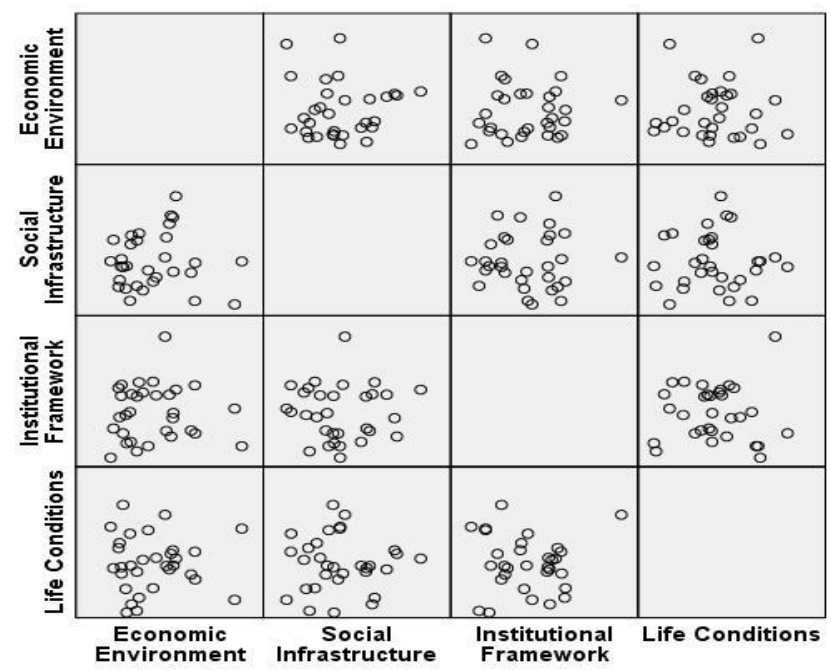

Source: Authors' own calculation 
Jovanović Gavrilović B., Gligorić M.: Fundamental drivers of prosperity in the...

On the LPI growth rate data for the 2007-2016 period we also used Cluster Analysis (K-means cluster), and the main results are presented in Tables 6 and 7. We defined four clusters. In the Iteration History table (Table 6) we can see how many iterations were enough before cluster centers substantially changed. The table shows that iteration was established already in the second step, which points out the stability of this four cluster model.

Table 6. Iteration History

\begin{tabular}{|l|l|l|l|l|}
\hline \multirow{2}{*}{ Iteration } & \multicolumn{4}{|c|}{ Change in Cluster Centers } \\
\cline { 2 - 5 } & 1 & 2 & 3 & 4 \\
\hline 1 & 0.132 & 0.121 & 0.146 & 0.101 \\
\hline 2 & 0.000 & 0.000 & 0.000 & 0.000 \\
\hline
\end{tabular}

Note: Convergence achieved due to no or small change in cluster centers. The maximum absolute coordinate change for any center is 0.000 . The current iteration is 2 . The minimum distance between initial centers is 0.321 .

Source: Authors' own calculation

Therefore, according to Cluster Analysis results, in the first cluster there are three countries, in the second cluster ten countries, in the third cluster four countries and in the fourth cluster 14 countries (see Tables 7 and 8).

Table 7. Number of Cases in each Cluster

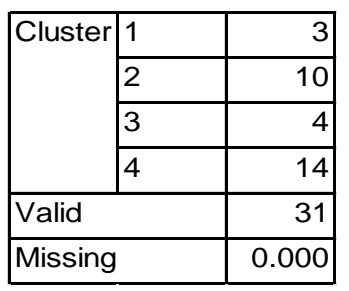

Source: Authors' own calculation

It can be noted that similarities in changes of LPI pillars, i.e. similarities in fundamental drivers of prosperity in the previous decade, are registered in Western Balkan countries (the first cluster), New Member States (NMS) countries (the second and third cluster) and old EU member states (EU-14) countries (the fourth cluster). In the first cluster there are three WB countries: Albania, Macedonia and Montenegro. Serbia, even though a WB country and a non EU country, according to Cluster Analysis belongs in the second cluster, namely, it had similar prosperity drivers in the last decade like most NMS (Croatia, Czech Republic, Estonia, Latvia, Lithuania, Malta, Poland, Romania) and one EU-14 country (Germany). In the third cluster there are 
Jovanović Gavrilović B., Gligorić M.: Fundamental drivers of prosperity in the...

NMS countries: Bulgaria, Hungary and Slovenia and one EU-14 country: Belgium. The fourth cluster consists of 12 old EU members and two new EU members - Slovakia and Cyprus.

Table 8. Cluster Analysis results

\begin{tabular}{|c|c|c|c|c|c|c|c|}
\hline \multicolumn{2}{|l|}{1} & \multicolumn{2}{|c|}{2} & \multicolumn{2}{|c|}{3} & \multicolumn{2}{|l|}{4} \\
\hline Albania & WB & Croatia & NMS & Belgium & EU-14 & Austria & EU-14 \\
\hline Macedonia & WB & Czech R. & NMS & Bulgaria & NMS & Cyprus & NMS \\
\hline Montenegro & WB & Estonia & NMS & Hungary & NMS & Denmark & EU-14 \\
\hline & & Germany & EU-14 & Slovenia & NMS & Finland & EU-14 \\
\hline & & Latvia & NMS & & & France & EU-14 \\
\hline & & Lithuania & NMS & & & Greece & EU-14 \\
\hline & & Malta & NMS & & & Ireland & EU-14 \\
\hline & & Poland & NMS & & & Italy & EU-14 \\
\hline & & Romania & NMS & & & Luxembourg & EU-14 \\
\hline & & Serbia & WB & & & Netherlands & EU-14 \\
\hline & & & & & & Portugal & EU-14 \\
\hline & & & & & & Slovakia & NMS \\
\hline & & & & & & Spain & EU-14 \\
\hline & & & & & & Sweden & EU-14 \\
\hline
\end{tabular}

Note: WB - Western Balkan countries, NMS - New EU member states countries, EU-14 - "old" member states countries.

Source: Authors' own calculation and representation

We can further look into the fundamental drivers of prosperity (pillar growth rates) that in general characterize countries in each of the four clusters. Countries are divided into clusters based on similarities of changes in Prosperity Index pillars, in a way that minimizes the variance in pillar value changes between countries grouped inside a cluster, and maximises the variance between clusters.

According to ANOVA table, variables with large $F$ values provide the greatest contribution in separation of countries between clusters. In our analysis those are Governance, Business Environment and Environment.

Figure 3 shows the cluster centers that are calculated as the mean value of variables (pillar growth rates) of countries in each cluster and reflect the characteristics of the "typical case" for each cluster. The figure points out the main distinctions regarding the change in value of certain LPI pillars (the drivers of prosperity) between European countries in different clusters in the 
Jovanović Gavrilović B., Gligorić M.: Fundamental drivers of prosperity in the...

previous decade, as well as some similarities of the drivers in observed countries.

We can conclude that countries in the first cluster registered a significant growth of the Business Environment pillar compared to the countries from other clusters. Countries in the first and second cluster noted growth of value of Governance, while third and fourth cluster countries recorded fall of that pillar compared to the initial (2007) value. Environment was the main prosperity driver in the third cluster, which separates that cluster significantly from the other three.

Figure 3. Final Cluster Centers

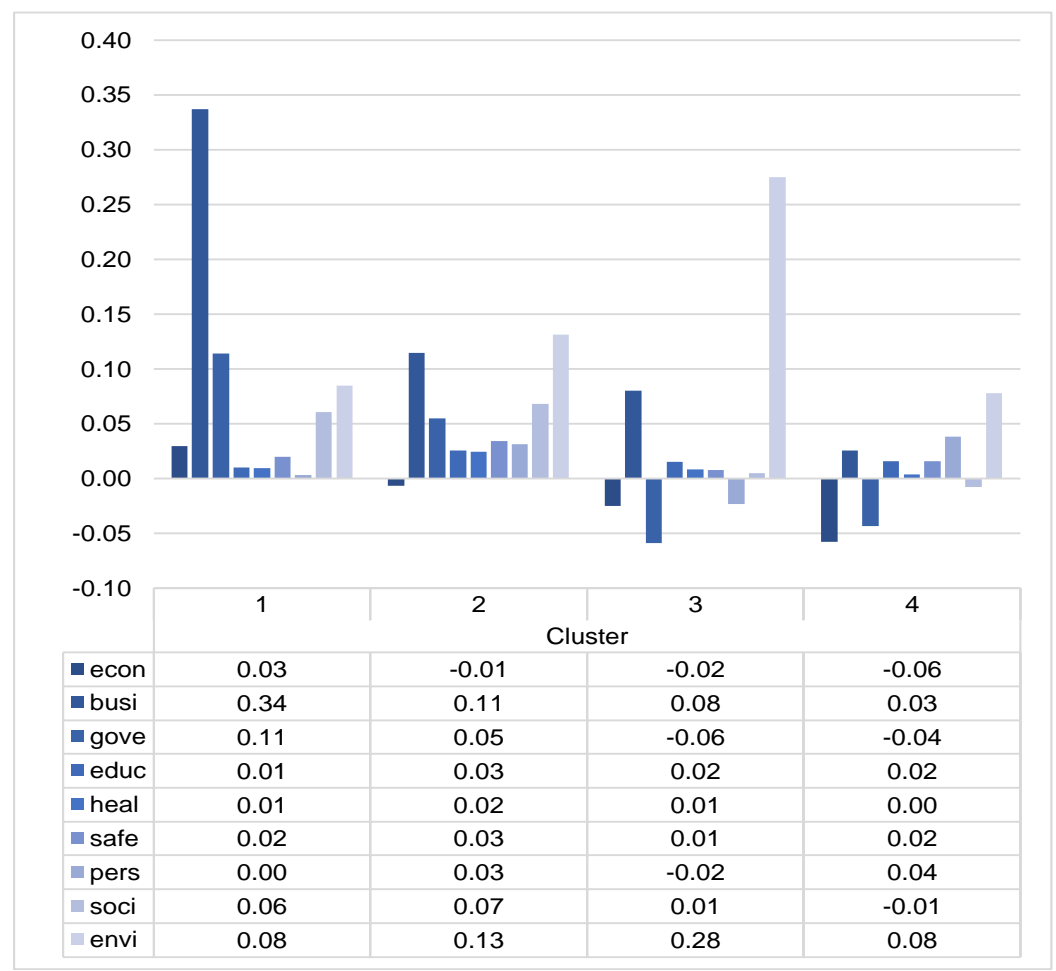

Note: econ - Economic Quality, busi - Business Environment, gove - Governance, educ Education, heal - Health, safe - Safety \& Security, soci - Social Capital, pers - Personal Freedom and envi - Environment.

Source: Authors' own calculation and representation

Therefore, in general, the key drivers of prosperity for the countries in the first cluster were Business Environment and Governance, as well as in somewhat less extent Environment and Social Quality. Countries belonging in the 
Jovanović Gavrilović B., Gligorić M.: Fundamental drivers of prosperity in the...

second cluster on average caracterised dominant improvement in values of Environment, then Business Environment and Social Quality pillars. Third cluster countries had dominant positive influence on prosperity from growth of Environment, followed by growth of Business Environment, while the average of cumulative growth rates implies drop in Governance value. In the fourth cluster, Environment was also dominant determinant of prosperity growth, while values of variables Governance and Economic Quality dropped considerably.

It is also important to note that there are many similarities between observed countries belonging to different clusters when it comes to value change in previous decade in some pillars, e.g. Education, Health and Safety and Security, which is probably result of the fact that most of the countries are members of the EU (others are candidate countries), and therefore their prosperity is in great extent determined by the huge volume of rules and regulations in different key areas.

Also, based on futher analysis we can conclude that Clusters 2 and 4 are the most similar. The biggest difference is between clusters 1 and 3 and 1 and 4 , and that difference is approximately similar (see Table 9).

Table 9. Distances between Final Cluster Centers

\begin{tabular}{|l|c|c|c|c|}
\hline Cluster & 1 & 2 & 3 & 4 \\
\hline 1 & & 0.241 & $\mathbf{0 . 3 7 3}$ & 0.368 \\
\hline 2 & & & 0.208 & 0.172 \\
\hline 3 & & & & 0.217 \\
\hline 4 & & & & \\
\hline
\end{tabular}

Source: Authors' own calculation

\section{Conclusions}

In this paper we wanted to identify which key determinants have contributed the most to the progress of European Union and Western Balkan countries in the 2007-2016 period. In detailed empirical research based on Legatum Prosperity Index data, we analysed cumulative change in values of each of nine LPI components/pillars and separated countries according to main drivers of their prosperity in ten years period.

Multivariate Data Analysis was implemented - the Principal Component Analysis and Cluster Analysis on the data for cumulative growth rate of LPI pillars.

Using the PCA, instead of nine original LPI components/pillars, we got four principal components: Economic Environment, Social Infrastructure, 
Jovanović Gavrilović B., Gligorić M.: Fundamental drivers of prosperity in the...

Institutional Framework and Life Conditions, on which further prosperity analysis is based. The countries with the highest positive and negative scores in each component, or more precisely, the countries that recorded the biggest growth/decline within each of the principal components, are distinguished with the help of four principal components and so-called score analysis.

According to results, progress of Serbia, Albania, Macedonia, Montenegro and Romania is in a great extent a consequence of a high Economic Environment improvement. In Baltic countries and Poland was registered exceptionally high increase in value in Social Infrastructure, which shows that their prosperity was based on this component. Austria, Finland, Malta and Portugal recorded a significant growth in Institutional Framework, while Belgium, Bulgaria, Hungary, Macedonia, Malta and Slovenia had positive and high score in Life Conditions. On the other side, greater decline in Economic Environment was registered in Denmark, Hungary and Spain. Albania, Belgium, Romania and Sweden had significantly bad score when it comes to Social Infrastructure. Negative score was recorded in Bulgaria, Cyprus, Greece, Hungary, Macedonia and Slovakia regarding Institutional Framework. Markedly negative values of Life Conditions score were registered in Albania, Cyprus, Finland, Greece and Ireland.

With Cluster Analysis based on data of LPI pillars growth rate, four clusters have been formed. The clusters consist of countries that were similar in the tempo of changes in Prosperity Index pillars, i.e. had similar fundamental drivers of prosperity in the previous decade. We have three WB countries in the first cluster: Albania, Macedonia and Montenegro. Even though Serbia is a WB country and is not a member of the EU, its prosperity drivers in the last decade were similar to most NMS (Croatia, Czech Republic, Estonia, Latvia, Lithuania, Malta, Poland, Romania) and one EU-14 country (Germany). Three NMS countries (Bulgaria, Hungary and Slovenia) and one EU-14 country (Belgium) are in the third cluster, while the fourth cluster comprises 12 old EU members and two new EU members - Slovakia and Cyprus.

Based on results of the Cluster Analysis we can conclude that the key drivers of prosperity for the countries were as follows: a) for the first cluster: Business Environment and Governance, as well Environment and Social Quality; b) for the second cluster: Environment, Business Environment and Social Quality pillar, c) for the third cluster: Environment, followed by Business Environment and $\mathrm{d}$ ) for the fourth cluster: Environment. Some similarities between the countries belonging to different clusters in (growth of) determinants are consequence of the fact that these countries are part of the same integration (EU) or have intention to join it, which implies harmonization of countries in different important areas and hence the ways/paths of achieving long-term prosperity. 
Jovanović Gavrilović B., Gligorić M.: Fundamental drivers of prosperity in the...

\section{References}

Altaş, D., \& Arikan, G. (2015). The Analysis of Human Development Index with Cluster Analysis Techniques. Social Sciences Research Journal, 6 (3), 126-138 (September 2017).Retrived from: http://dergipark.gov.tr/download/articlefile/347532.

Biswas, B., \& Caliendo, F. (2002). A multivariate analysis of the human development index. In Economics Research Institute Study Paper. 244. Retrived from: https://digitalcommons.usu.edu/cgi/viewcontent.cgi?article=1243\&context=eri.

Giray, S., \& Ergut, O. (2014). Multivariate Analysis of Countries according to Subdimensions of Human Development and Gender Inequality Indices. Eurasian Journal of Social Sciences, 2(3), 48-62. doi:10.15604/ejss.2014.02.03.004

Gligorić, M., Jovanović Gavrilović, B., \& Savić, (2018). Prosperity Index as a measure of wellbeing in European Union and Western Balkan Countries. Teme, (accepted for publishing).

Hair, J., Black, W., Babin, B., \& Anderson, R. (2014). Multivariate Data Analysis. London: Pearson Education Limited.

-IBM. (2012). IBM Knowledge Center. Retrived from: https://www.ibm.com/support/knowledgecenter/.

Jovanović Gavrilović, B., Gligorić, M., \& Molnar, D. (2012). The Importance of the Quality of Economic Growth in the search for a Way out of the Crisis. In B. Cerović, M. Jakšić, Z. Mladenović, \& A. Praščević (Eds.), From Global Crisis to Economic Growth: Which Way to Take?. University of Belgrade, Faculty of Economics: Belgrade. Volume I, Economics (pp. 629-650).

-Legatum Institute. (2008). Legatum Prosperity Index Report, Methodology, Data and Findings.

-Legatum Institute. (2016). The Legatum Prosperity Index 2016, Legatum Methodology Report, Bringing Prosperity to Life.

-Legatum Institute. (2016). Europe: Prosperity is Raising: Why is it uneven between Western and Eastern Europe?. Retrived from: http://www.prosperity.com/feed/regional-analysis-europe.

-Legatum Institute. (2016). Prosperiyty rankings: Full data set. Retrived from: http://www.prosperity.com/about/resources.

-Legatum Institute. (2017). The Legatum Prosperity Index.

-OECD. (2008). Handbook on constructing composite indicators: Methodology and user guide. Joint Research Centre-European Commission. OECD publishing.

Shaker, R.R., \& Zubalsky, S.L. (2014). Examining patterns of sustainability across Europe: a multivariate and spatial assessment of 25 composite indices. International Journal of Sustainable Development \& World Ecology, 22(1), 1-13. doi:10.1080/13504509.2014.923058

Sima, V.,\& Gheorghe, I. G. (2017). A multicriterial analysis of national competitiveness: Evidences for a resilient economy. Industrija, 45(2), 45-64.

Stiglitz, J., Sen, A., \& Fitoussi, J.P. (2009). Report by the commission on the measurement of economic performance and social progress. Retrived from: http://ec.europa.eu/eurostat/documents/118025/118123/Fitoussi+Commission+r eport. 